\title{
Lingkungan Hidup Dan Permasalahannya Dalam Interpretasi Tokoh Agama Buddha: Studi Kasus Kebakaran Hutan Dan Lahan
}

\author{
Joko Santoso ${ }^{1,3}$, Sulmin Gumiri ${ }^{1,2}$, Nina Yulianti ${ }^{1,2}$, Masliani ${ }^{1,2}$ \\ 1)Program Studi Doktoral Ilmu Lingkungan, Program Pascasarjana Universitas \\ Palangka Raya \\ 2)Fakultas Pertanian, Universitas Palangka Raya \\ 3)BIMAS Buddha, Kementerian Agama Republik Indonesia
}

\begin{abstract}
ABSTRAK
Kehidupan manusia dan isinya tidak lepas dari lingkungan yang berhubungan erat saling memberikan sumbang sih dalam proses berkelanjutan hidup, banyak permasalahan lingkungan yang timbul seperti kebakaran hutan dan lahan, banjir, longsor. Faktor utama permasalahan ini dilakukan oleh manusia. Masalah lingkungan yang sangat penting terutama di era abad 21 di Indonesia yaitu efek rumah kaca dan pemanasan global, penipisan lapisan ozon, hujan asam, pencemaran lingkungan, degradasi hutan dan berkurangnya luas hutan dan penurunan kualitas sumber daya alam. Banyak upaya yang dilakukan oleh semua pihak dalam menangani permasalah lingkungan agar terjaga dan tidak terus terjadi sepert kebakaran hutan dan lahan yang terjadi dibeberapa wilayah Indonesia, seperti di kalimantan Tengah kejadian kebakaran hutan dan lahan setiap tahun terjadi baik sekala kecil maupun besar hal ini menjadi perhatian semua pihak tak terkecuali para tokoh umat Buddha yang menjadi kuci pokok dalam pembinaan untuk mengarahkan umat Buddha dalam upaya menjaga lingkungan dengan berbagai cara. Penelitian ini dilakukan di tiga wilayah Kota Palangka Raya. Kabupaten Kotawaringin Timur dan Kabupaten Kotawaringin Barat. Metode penelitian ini adalah wawancara kepada tokoh Agama Buddha. Penelitian kualitatif berhubungan dengan ide, persepsi, pendapat, atau kepercayaan orang yang diteliti; kesemuanya tidak dapat diukur dengan angka (Sulistyo-Basuki, 2006). Penelitian ini bertujuan untuk mengetahui interpretasi umat Buddha dalam menangani permasalahan lingkungan dalan studi kasus kebakaran hutan dan lahan di Kalimantan Tengah. Kesimpulan dari penelitian ini adalah adanya peran nyata para umat Buddha dan tokoh agama Buddha dalam menangani permasalahan lingkungan akibat kebakaran hutan dan lahan memalui penyiaran ajaran Buddha dan kegiatan pelestarian lingkungan dengan cara fangshen (pelepasan makluk hidup), membersikhkan lingkungan dari sampah dan melakukan reboisasi.
\end{abstract}

Keywords: Lingkungan, Kebakaran, umat Buddha, Ajaran Buddha;

\section{PENDAHULUAN}

Lingkungan hidup dan permasalahannya pada era abad 21 merupakan isu lingkungan yang banyak bermunculan pada abad modern sekarang ini dimana industri tidak dapat dipisahkan dari kehidupan dan kebutuhan manusia. Pengelolaan dan memanfaatan lingkungan yang tidak sesuai dengan aturan akan menimbulkan banyak masalah terhadap lingkungan yang dampaknya akan di rasakan dalam waktu yang singkat. Masalah lingkungan yang sangat penting terutama di era abad 21 di Indonesia yaitu efek rumah kaca dan pemanasan global, penipisan lapisan ozon, 
hujan asam, pencemaran lingkungan, pencemaran lingkungan, degradasi hutan dan berkurangnya luas hutan dan penurunan kualitas sumber daya alam (Yasin dkk, 2019). Manusia dan seluruh entitas kehidupan dalam memenuhi semua aspek kebutuhannya akan bersinggungan dengan lingkungan sehingga menimbulkan dampak. Maka dari itu setiap aspek kegiatan manusia, wajib memperhatikan yang namanya aspek perlindungan dan pengelolaan lingkungan yang sesuai dengan aturan agar tetap terjaga keseimbangan yang harmonis dalam tatanan ekologi. Sangat pentingnya peran dan fungsi lingkungan hidup bagi kehidupan manusia dan seluruh makluk di bumi, upaya dalam tata pengelolaan dan perlindungan lingkungan hidup menjadi prioritas yang harus dilakukan oleh seluruh umat manusia, supaya kelangsungan sistem tata kehidupan tetap terjaga dengan baik walaupun ada perubahan. Upaya perlindungan kepada keberlanjutan lingkungan (ekologis)sangat penting sebagai salah satu indikator pembangunan berkelanjutan yang dicanangkan oleh Perserikatan Bangsa Bangsa pada tanggal 2 Agustus 2015(BPS, 2018).

Pada tahun 2019, kebakaran hutan dan lahan gambut terjadi cukup parah akibat pengaruh kondisi iklim global yaitu kemarau panas yang dipengaruhi El Nino. Penyebab kebakaran lainnya adalah semakin meningkatnya intensitas aktivitas manusia pada suatu kawasan hutan dan lahan gambut di Kalimantan Tengah, misalnya untuk pembersihan lahan(lahan kering dan lahan gambut),ladang (lahan kering), berburu binatang liar, memancing ikan, membakar sampah pertanian dan rumah tangga, pencarian kayu galam dan penyebab lain-lain (Akbar, 2007). Konsekuensinya, jumlah titik panas (hotspot) pada tahun tersebut adalah masuk dalam 4 (empat) kejadian terparah setelah 2015, 2006, dan 2009 seperti hasil penelitian terdahulu dalam Yulianti dkk (2020). Dampak dari kebakaran hutan dan lahan ini adalah pada berbagai aspek, seperti degradasi hutan dan lahan gambut, pencemaran lingkungan (tanah, air dan udara), gangguan produktivitas tanaman, kesehatandan sosial ekonomi masyarakat. Dengan hilangnya ratusan hektar hutan tropis dan lahan gambut, maka tingkat emisi karbon semakin meningkat. Emisi karbon merupakan salah satu sumber gas rumah kaca yang menyebabkan pemanasan global dan perubahan iklim. Selain itu, kebakaran hutan dan lahan diduga berdampak pada KeputusanPresiden tentang dipindahkannyacalon ibukota baru ke Provinsi Kalimantan Timur dan bukan Provinsi Kalimantan Tengah. Jadi, kerugian akibat bencana tahun 2019 tersebut tidak hanya berdampak sesaat tetapi juga jangka panjang baik secara lokal, nasional dan global.

Permasalahan bencana kebakaran hutan dan lahan gambut memerlukan perhatian semua pihak termasuk komunitas umat beragama dalam memaksimalkan upaya pencegahan dan mitigasi. Hal ini mengingat Indonesia merupakan salah satu negara di dunia yang mengakui agama dalam tatanan kehidupannya.Agama Buddha atau Buddhisme adalah agama terbesar keempat di dunia atau lebih 7 (tujuh) persen populasi dunia Michael Keene, Agama-agama Dunia (2006). Sedangkan keberadaan 
umat Buddha di Kalimantan Tengah tergolong minoritas. Berdasarkan data statistik tahun 2017(BPS, 2017), jumlah pemeluk agama menurut kabupaten/kota di Provinsi Kalimantan Tengah terdapat sebanyak 17.950 orang umat Buddha atau sekitar 0,63\% dari jumlah penduduk Kalimantan Tengah. Sebagian besar umat Buddha yaitu sebanyak 6.500 orang atau 36,19\% terdapat di Kabupaten Kotawaringin Timur, sebanyak 5.350 orang atau 29,79\% terdapat di Kabupaten Kotawaringin Barat dan sebanyak 3.000 orang atau 16,70\% terdapat di Kota Palangka Raya menurut data Bimas Buddha Kantor Wilayah Kementerian Agama Provinsi Kalimantan Tengah tahun 2018. Agama Buddha lahir di India kuno sebagai suatu tradisi Sramana sekitar antara abad ke-6 dan 4 SM pada tahun 523 SM (sebelum Masehi), menyebar ke sebagian besar Asia termasuk Indonesia. Buddha dikenal oleh para umat-Nya sebagai seorang guru yang telah sadar atau tercerahkan dan mengajarkan atau membagikan wawasan-Nya untuk membantu makhluk hidup mengakhiri penderitaan mereka dengan melenyapkan ketidaktahuan / kebodohan (/kegelapan batin (moha), keserakahan (lobha), dan kebencian/kemarahan (dosa). Berakhirnya atau padamnya moha, lobha, dan dosa disebut dengan Nibbana. Untuk mencapai Nibbana seseorang melakukan perbuatan benar, tidak melakukan perbuatan salah, mempraktikkan meditasi untuk menjaga pikiran agar selalu pada kondisi yang baik atau murni dan mampu memahami fenomena batin dan jasmani (Kita Suci Tripitaka bagian Kitab Anggutara Nikaya V.161),

Natthi dosasamo gaho.

Natthi mohasamaì jālami.

Natthi tanhā samā nadì.

Tidak ada cengkraman yang lebih kuat dari kebencian.

Tidak ada jaringan yang lebih rapat dari kebodohan.

Tidak ada sungai yang arusnya lebih deras dari nafsu keinginan.

(Dhammapada 251)

Filosofi Buddha terhadap lingkungan adalah Dharma, Dharma (ajaran) menghubungkan lingkungan alam dan hubungan manusia yang berguna untuk menciptakan suatu atmosfir kebahagiaan di dalam kehidupan di atas bumi serta alam semesta. Buddhis menunjukkan cara pemecahan masalah krisis lingkungan. Sehubungan dengan pandangan ekologis Buddhis memperkuat sikap ramah kepada alam dan menelisik hubungan manusia, tumbuh-tumbuhan, dan binatang dari sudut keselarasan. Paradigma perlindungan dan pengelolaan lingkungan menurut ajaran agama Buddha tercermin dari ayat suci ini, "Bagai seekor lebah yang tidak merusak kuntum bunga, baik warna maupun baunya, pergi setelah memperoleh madu, begitulah hendaknya orang bijaksana mengembara dari desa ke desa" (Dhp. 49). Dalam ekosistem, lebah tidak hanya mengambil keuntungan dari bunga, tetapi juga sekaligus membayarnya dengan membantu penyerbukan. Perilaku lebah memberi inspirasi, bagaimana seharusnya menggunakan sumber daya alam yang terbatas 
tidak di dasarkan dengan keserakahan (lobba) yang akan membuat semua makluk semakin menderita. "Hendaklah ia berpikir semoga semua makhluk berbahagia. Makhluk hidup apapun juga, yang lemah dan yang kuat tanpa kecuali, yang panjang atau yang besar, yang sedang, pendek, kecil atau gemuk, yang tampak atau tak tampak, yang jauh ataupun yang dekat, yang terlahir atau yang akan lahir, semoga semua makhluk berbahagia". Hal ini mengandung arti bahwa agama Buddha menolak terjadinya pencemaran dan perusakan alam dan segenap potensinya. Maka dari itu perlu dilakukan penelitian kepada umat Buddha berkaitan dengan kondisi kebakaran hutan dan lahan yang terjadi di wilayah Kalimantan Tengah sehingga umat Buddha dapat berkontribusi dalam menjaga keamanan wilayah dari kebakaran hutan dan lahan dengan berbagai cara yang sesuai dengan ajaran Buddha secara arif dan bijaksana

Penelitian sebelumnya tentang gerakan agama dan lingkungan hidup dengan sangat jelas Buddha mengapresiasi peran hutan, pohon, dan alam yang sangat bermanfaat bagi kehidupan (World Bank, 2006; Anwar, 2009; Thathong, 2012; Somaratne, 2017).Kata 'Vana' atau hutan dalam Dhammapada digunakan oleh Buddha sebagai perumpamaan kata-kata penuh arti diberlakukan bagi konteks dunia saat ini: tebanglah hutan (nafsu) sampai habis, jangan tinggalkan satu pohon pun. Dari hutan itulah tumbuh rasa takut (Dhp.283). Penelitian terdahulu hanya mengupas tentang ajaran Buddha dengan lingkungan secara global, belum mengarah yang spesifik seperti tentang kebakaran hutan dan lahan gambutyang terjadi (Rajapaksha dkk, 2016; Situmorang dan Silalahi, 2017; Mulyana, 2019). Dalam Vinaya Buddha menetapkan bahwa seorang bhikkhu yang menyebabkan kerusakan pada tanaman dinyatakan bersalah. Agama Buddha mengenai sikap tanpa kekerasan, tidak hanya berlaku terhadap semua makhluk hidup, tetapi juga terhadap tumbuh-tumbuhan dan alam (Setiadi, 2018). Oleh karena itu, penelitian ini bertujuan untuk menjelaskan konsep agama Buddha tentang lingkungan dan permasalahannya, mengemukakan pandangan tokoh agama Buddha dan mengidentifikasikan aktivitas pelestarian lingkungan dalam Komunitas Umat Buddhaterutama di Kalimantan Tengah.

\section{METODE}

\section{Lokasi Penelitian}

Penelitian ini akan dilakukan di Provinsi Kalimantan Tengah dan secara sengaja dipilih di wilayah Kota Palangka Raya, Kabupaten Kotawaringin Timur dan Kabupaten Kotawaringin Barat). Sebaran lahan gambut yang menjadi prioritas restorasi pasca kebakaran hutan dan lahan gambut tahun 2015 di Provinsi Kalimantan Tengah ditunjukkan pada Gambar 1. Ketiga lokasi penelitian ini termasuk dalam area tersebut (ditunjukkan deng tanda bintang pada Gambar 1). Pembentukan lahan gambut di Palangka Raya dipengaruhi oleh Sungan Kahayan dan Sebangau. 
Pembentukan lahan gambut di Kotawaringin Timur dipengaruhi oleh Sungai Mentaya dan Sungai Pukun. Pembentukan lahan gambut di Kotawaringin Barat dipengaruhi oleh Sungai Lamandau dan Sungai Arut. Hal tersebut juga mempengaruhi pola sosial budaya masyarakat setempat.

Menurut data statistik (BPS, 2017), $\mathrm{t}$ otal umat Buddha adalah 0.17\% dari total penduduk Palangka Raya, $0.29 \%$ dari total penduduk Kotawaringin Timur dan 0.33\% dari total penduduk Kotawaringin Barat.Kota Palangka Raya memiliki penduduk yang memeluk agama Buddha berjumlah \pm 4.500 jiwa dengan memiliki 5 vihara. Kabupaten Kotawaringin Timur yang memiliki jarak 221,9 Km dari Ibu Kota Provinsi Kalimantan Tengah Palangka Raya yang memiliki jumlah pemeluk agama Buddha \pm 6.000 jiwa, bernaung di 3 vihara. Kabupaten Kotawaringin Barat memiliki jumlah pemeluk agama Buddha cukup lumayan banyak sekitar 4.300 jiwa yang memiliki 2 vihara. Jumlah pemeluk Agama Budha pada satu vihara berkisar antara 900 jiwa sampai dengan 1.550 Jiwa.

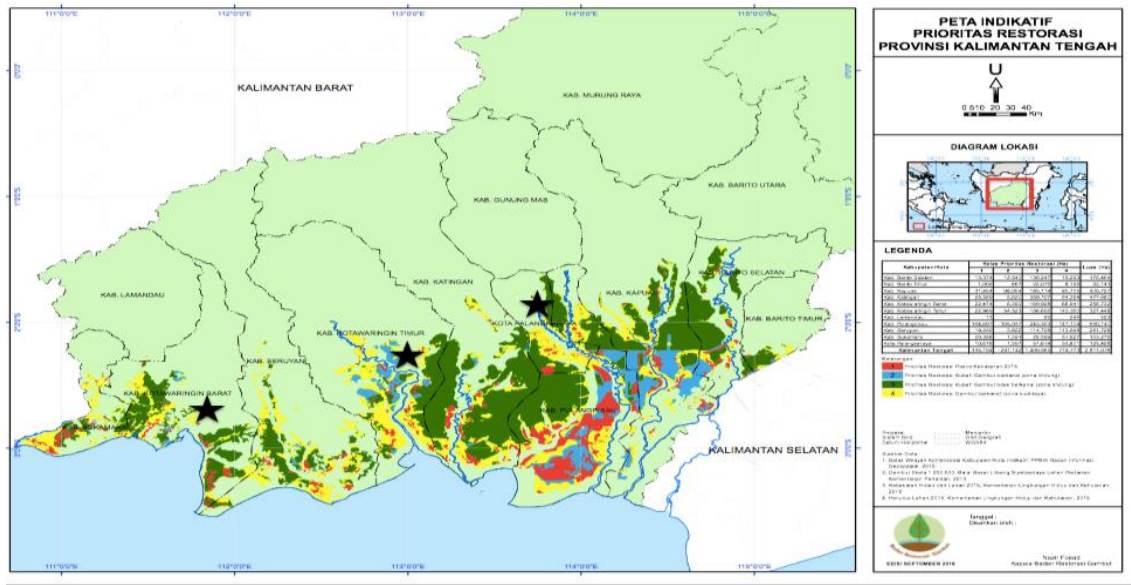

Gambar 1. Lokasi Penelitian dan Area Prioritas Restorasi Lahan Gambut

\section{Pengumpulan Data}

Metode pengumpulan data yang dilakukan pada penelitian ini adalah metode survei yang informasinya akan dikumpulkan dari beberapa sampel terpilih. Metode ini merupakan cara yang umum dilakukan pada penelitian kualitatif. Penelitian kualitatif berhubungan dengan ide, persepsi, pendapat, atau kepercayaan orang yang diteliti; kesemuanya tidak dapat diukur dengan angka (Sulistyo-Basuki, 2006). Wawancara tokoh Agama Buddha terdiri dari 3 (tiga) orang dari Palangka Raya, 2 (dua) orang dari Kotawaringin Timur dan 2 (dua) orang dari Kotawaringin Barat. Informan pada penelitian kualitatif ini dipilih dan ditentukan dengan pertimbanganpertimbangan tertentu yang telah ditentukan oleh peneliti. Masing-masing tokoh mewakili berbagai tingkatan diantaranya Ketua Vihara, Penyuluh Agama Buddha dan Ketua MAHASI Kalteng. Data hasil wawancara ditampilan dalam bentuk tabulasi. Data sekunder pada penelitian ini adalah data yang diperoleh dari teknik 
pengumpulan data yang menunjang data primer yang bersumber dari kitab suci, buku religi, jurnal, laporan tahunan, literature dan dokumen lain yang berhubungan dengan masalah penelitian.

\section{HASIL DAN PEMBAHASAN}

\section{Konsep Ajaran Buddha dan Lingkungan Hidup}

Asal mula Agama Buddha dari negara India dan juga dari wilayah Nepal, Agama Buddha ada merupakan reaksi terhadap agama Brahmanisme. Sejarah agama Buddha mulai dari abad ke-6 SM sampai sekarang yang menjadi salah satu agama terbesar di dunia dengan jumlah penganut 521 juta (Pew Research Center, 2015) . Pembawa ajaran Agama Buddha adalah Sidharata Gaoutama yang merupakan Putra Raja Sudhodana yang lahir pada tahun 523 SM dan bertekat meninggalkan kehidupan duaniawi. Sidharta Gautama bertapa dan mencapai Penerangan Sempurna untuk mencari jalan mengahiri penderitaan setiap makluk. Ajaran Sang Buddha yang pertama kali diajarakan adalah Ajaran dasar dikenal sebagai Empat Kebenaran Mulia atau Empat Kebenaran Ariya (Cattari Ariya Saccani) merupakan aspek yang sangat penting dari ajaran Buddha sebagai berikut, 1) Dunia ini adalah Penderitaan ( Dukkha Sacca : Kebenaran tentang Dukha), 2) Sebab penderitaan adalah Nafsu Keinginan ( Tanha ) -> Samudaya Sacca, 3) Berakhirnya Penderitaan (Nibbana) -> Nirodha-Sacca, 4) alan Menuju Berakhirnya Penderitaan ( Ariya Athangika Magga ; Jalan Arya / Mulia beruas Delapan ) -> Magga-Sacca. Agama Buddha adalah salah satu agama tertua yang masih dianut di dunia.Agama Buddha berkembang dengan unsur kebudayaan India, ditambah dengan unsur-unsur kebudayaan Helenistik (Yunani), Asia Tengah, Asia Timur dan Asia Tenggara. Dalam proses perkembangannya, agama ini praktis telah menyentuh hampir seluruh benua Asia dan telah menjadi agama mayoritas di beberapa negara Asia seperti Thailand, Singapura, Kamboja, Myanmar, Taiwan, sampai ke negara Tiongkok pada tahun $\underline{399}$ Masehi.

Setiap aliran Buddha berpegang kepada Tripitaka sebagai rujukan utama karena dalamnya tercatat sabda dan ajaran sang hyang Buddha Gautama. Pengikutpengikutnya kemudian mencatat dan mengklasifikasikan ajarannya dalam 3 buku yaitu Sutta Pitaka (kotbah-kotbah Sang Buddha), Vinaya Pitaka (peraturan atau tata tertib para bhikkhu) dan Abhidhamma Pitaka (ajaran hukum metafisika dan psikologi).

Dalam agama Buddha juga disebut sebagai TRI RATNA yang artinya tiga perlindungan yang terdiri dari :

1. Buddha, sebagai perlindungan pertama, mengandung arti bahwa setiap orang mempunyai benih kebuddhaan dalam dirinya, bahwa setiap orang dapat mencapai apa yang telah dicapai oleh Sang Buddha. "Seperti sayalah para penakluk yang telah melenyapkan kekotoran batin" (Ariyapariyesanâ 
Sutta, Majjhima Nikâya). Sebagai perlindungan, Buddha bukanlah pribadi Petapa Gotama, melainkan para Buddha sebagai manifestasi daripada Bodhi (kebuddhaan) yang mengatasi keduniawian (lokuttara).

2. Dhamma, sebagai perlindungan kedua, bukan berarti kata-kata yang terkandung dalam kitab suci atau konsepsi ajaran yang terdapat dalam batin menusia biasa yang masih berada dalam alam keduniaan (lokiya, mundane), melainkan "Empat Tingkat Kesucian" beserta 'Nibbâna' yang dicapai pada akhir jalan.

3. Sangha, sebagai perlindungan kedua, bukan berarti kumpulan para bhikkhu yang anggota-anggotanya masih belum bebas dari kekotoran batin (bhikkhu sangha), melainkan Pasamuan Para Suci yang telah mencapai TingkatTingkat Kesucian (ariya-sangha). Mereka ini menjadi teladan yang patut dicontoh. Namun landasan sesungguhnya dari Perlindungan ini ialah kemampuan yang ada pada setiap orang untuk mencapai tingkat- tingkat kesucian itu. Ajaran Sang Buddha adalah realistis bisa di buktikan kebenannya yang merupakan ajara atas dasar pengalaman, inti sari ajaran Buddha adalah JANGAN BERBUAT JAHAT, PERBANYAKLAH PERBUATAN BAIK, SUCIKAN HATI DAN PIKIRAN. Ajaran Buddha secara sederhana dikemas untuk mudah di pahami oleh banyak orang yang ingin mengetahui dan mempelajari ajaran Buddha, dapat di pahami dan di jelaskan menjadi tiga yaitu :

1) Sains Buddha tentang cita - bagaimana pencerapan, pemikiran, dan perasaan bekerja dari sudut pandang pengalaman subjektif. Sains Buddha melengkapi ilmu saraf modern dengan menyediakan peta luas tentang berbagai fungsi kognitif (pengetahuan) cita, yang meliputi pencerapan pancaindera, daya pemusatan, perhatian, kehati-hatian dan ingatan, serta perasaan-perasaan positif dan negatif kita. Dengan merambah jalan rintis saraf yang positif, kita dapat meningkatkan kemampuan-kemampuan cita yang bermanfaat. Pada tingkat ragawi, sains Buddha juga mencakup tata medis mutakhir yang memuat pengobatanpengobatan untuk berbagai penyakit. Pada unsur eksternal, sains Buddha menyajikan uraian rinci tentang zat dan tenaga, dengan banyak kesamaan pada fisika kuantum. Ini juga membahas asal-usul, kelangsungan hidup, dan akhir alam semesta, menegaskan arus alam semesta sebelum ini tanpa ada awalnya.

2) Filsafat Buddha - budi pekerti dan nalar, dan pemahaman ajaran Buddha tentang kenyataan. Filsafat Buddha berurusan dengan persoalanpersoalan seperti saling kebergantungan, kenisbian, dan sebab-akibat. Filsafat Buddha menyajikan tata nalar yang rinci, berdasar pada 
seperangkat teori dan adu pendapat yang membantu kita untuk memahami pencitraan cita (pemikiran) kita yang keliru.

3) Agama Buddha - kepercayaan pada kehidupan-kehidupan masa lalu dan masa depan, karma, ibadat, dan doa. Budi pekerti Buddha didasarkan pada pembedaan antara apa yang bermanfaat dan apa yang berbahaya, baik bagi diri sendiri dan orang lain. Ini memerlukan penghargaan dan pengembangan nilai-nilai dasar kemanusiaan yang berupa kebaikan, kejujuran, kemurahan hati, dan kesabaran, sambil berusaha sekeras mungkin untuk tidak merugikan orang lain. Keagamaan Buddha berurusan dengan pokok-pokok seperti karma, kehidupan masa lalu dan masa depan, kelahiran kembali, kebebasan dari kelahiran kembali, dan pencapaian pencerahan. Ini meliputi laku-laku seperti nyanyian, meditasi, dan doa. Tidak ada kitab suci tunggal dalam ajaran Buddha, seperti "Injil Buddha," karena tiap aliran memiliki naskah-naskahnya sendiri berdasar pada ajaran-ajaran asli. Orang-orang bisa berdoa kapanpun atau di manapun, meskipun banyak yang memilik untuk melakukannya di candi-candi atau di depan kuil-kuil di rumah mereka. Tujuan doa ini bukan untuk terkabul harapan-harapannya, tetapi untuk membangunkan kekuatan batin, kebijaksanaan, dan welas asih kita.

Ajaran Buddha yang lebih dikenal dengan nama Dhamma yang diuraiakan oleh Sang Buddha dengan bertujuan untuk mencapai kebahagiaan sejati yaitu Nibhana / Nirvana ini sudah di sampakan sejak 2564 tahun yang lalu kepada umat manusia dan para Dewa yang menekankan ajaran cinta kasih yang unuversal serta ajaran yang menitiberatkan dalam pengendalian diri. Dharma yang terbagi dalam kitab Suci Tripitaka yaitu Vinaya Pitaka, Sutta Pitaka dan Abdhidhamma Pitaka merupakan ajaran Sang Buddha yang menjadi sumber terbebasnya penderitaan. Dharma mengajarankan pokok poin untuk mencapai kebebasan penderitan setiap makluk hidup, Dharma Sang Buddha ini tertuang dalam kita Suci Agama Buddha yang lebih di kenal dengan sebuatan TRI PITAKA, dalam sekema sebgai berikut :

\section{Vinaya Pitaka}

Vinaya Pitaka adalah bagian pertama dari tiga bagian Tripitaka, kitab suci agama Buddha. Bagian ini berisi hal-hal yang berkenaan dengan peraturan-peraturan bagi para bhikkhu dan bhikkhuni yang terdiri atas 3 bagian: Suttavibhanga, Khandhaka, Parivara. Vinaya Pitaka ini mengtur semua peraturan yang mengarah kepada pengendalian diri terhadap nafsu-nafsu duniawi yang menyebabkan penderitaan untuk diri sendiri dan makluk lain. Vinaya Pitaka juga menekankan bagaina pelaksanaan peraturan yang di iplemetasikan untuk menjaga dan menghargai lingkungan supaya menghindari terjadinya bencana alama, dengan cara 
pengedalian diri dengan tekun melaksanakan sila dalam Vinaya akan memberikan dampak positif terhada alam dan lingkungan. Vinaya atau sila ini memberikan batasan seseorang dalam bertindak kejahatan dan mengatur agar moralitas manusia menjadi baik, tidak merugikan orang lain maupun alam sekitar. Maka dengan pelatihan sila atau moralitas dengan baik siklus kehidupan maklu hidup akan berjalan dengan lancar dann tidak akan terjadi pergolakan serta penderitaan yang setrus berkembang (Gambar 2).

Sang Buddha mengajarkan dasar dalam mencapai pembebasan yaitu pelaksanaan Vinaya atau perturan etika dan moraritas dalam kehidupan dengan benar, agar manusia dapat menjaga rotasi kehidupan dengan baik. Namun jaman sekaran ini banyak orang sudah lepas dalam memegang teguh aturan atau vinaya yang berakibat banyak terjadinya penderitaan baik penderitaan secara batin maupun penderitaan secara fisik. Penderitaan secar batin dimana manusia terbelenggu oleh sifat serakah, egois, malas, kebencian dan cenderung pikiran tidak terkendali dengan baik, inilah sebab yang selalu terjadi kemerosotan kualitas batin manusia. Pikiran menjadi kunci utama dalam mengatur semua prilaku dan tindakan manusia, seperti yang telah Sang Buddha sabdahkan :

Manopubbangamā dhammā, manosețthā manomayā; Manasā ce paduțțhena, bhāsati vā karoti vā;Tato nam dukkhamanveti, cakkaṃva vahato padam.

Artinya: Pikiran adalah pelopor dari segala sesuatu, pikiran adalah pemimpin, pikiran adalah pembentuk. Bila seseorang berbicara atau berbuat dengan pikiran jahat,maka penderitaan akan mengikutinya, Bagaikan roda pedati mengikuti langkah kaki lembu yang menariknya (Kitab Suci Dhamapada, 2002: 50)

Banyak orang yang mengganggap peran utama pikiran tidak menjadi prioritas, sehingga kekotoran batin dan kualitas batin menurun, perilaku setiap manusia yang buruk akan menimbulkan hal yang menyebabkan kekacoan sehingga kondisi alam akan menjadi terpengaruh oleh sikap dan prilaku manusia, banyak sifat serakah yang dikedepankan guna memenuhi keinginan pribadi tanpa memperhatikan lingkungan sekitar. Contohnya di Indonesia setiap tahun selalu terjadi bencana banjir, gunung meletus dan kebakaran hutan dan lahan, seperti kebakaran hutan dan lahan di Indonesia yang terjadi di beberapa provisi menjadikan kondisi alam berubah dan tingkat kehidupan manasia juga bermasalah. Kabakaran hutan dan lahan setiap tahun selalu terjadi baik sekala besar maupun kecil tergantung kondisi iklim yang menjadi tingkat kebakaran hutan dan lahan. Hal ini tidak lepas dari ulah manusia yang mementingkan diri sendiri dan tidak memiliki sila atau vinaya dengan baik. Kita tidak pernah sadar bahwa Lingkungan hidup sebagai tempat beraktivitas

Hal yang paling utama dan tak boleh dilupakan adalah bahwa lingkungan hidup merupakan tempat beraktivitas semua makhluk hidup. Manusia, hewan dan tumbuhan selalu beraktivitas di lingkungan hidup. Hewan dan tumbuhan menggunakan lingkungan hidup sebagai tempat menjalani kehidupannya. Tempat 
mencari makan, tempat berkembangbiak, tempat berburu dan lain- lain. Manusia menggunakan lingkungan hidup sebagai tempat beraktivitas secara lebih kompleks lagi. Manusia mempunyai beberapa kelompok lingkungan hidup, diantaranya adalah lingkungan social dan lingkungan alam. Lingkungan alam dan social sama- sama memberikan fungsi sebagai tempat beraktivitas manusia. Lingkungan alam sudah jelas terlihat fungsinya, sedangkan lingkungan social memberikan ruang beraktivitas sesama manusia untuk saling berkomunikasi. Lingkungan hidup sebagai penyedia unsur- unsur penting. Secara alami, lingkungan hidup bermanfaat sebagai penyedia unsur- unsur penting yang dibutuhkan makhluk hidup. Unsur- unsur penting tersebut diantaranya adalah oksigen, air dan mineral. Oksigen, air dan mineral merupakan unsur- unsur pokok yang dibutuhkan makhluk hidup untuk melangsungkan kehidupan. Oksigen digunakan untuk bernafas, air digunakan hampir diseluruh kegiatan makhluk hidup dan mineral digunakan sebagai pendukung pokok kelangsungan hidup makhluk hidup. Oleh sebab itu Sang Buddha sangat menekankan dalam pengedalian diri serta menjaga moralitas Dengan baik dan terkendali.

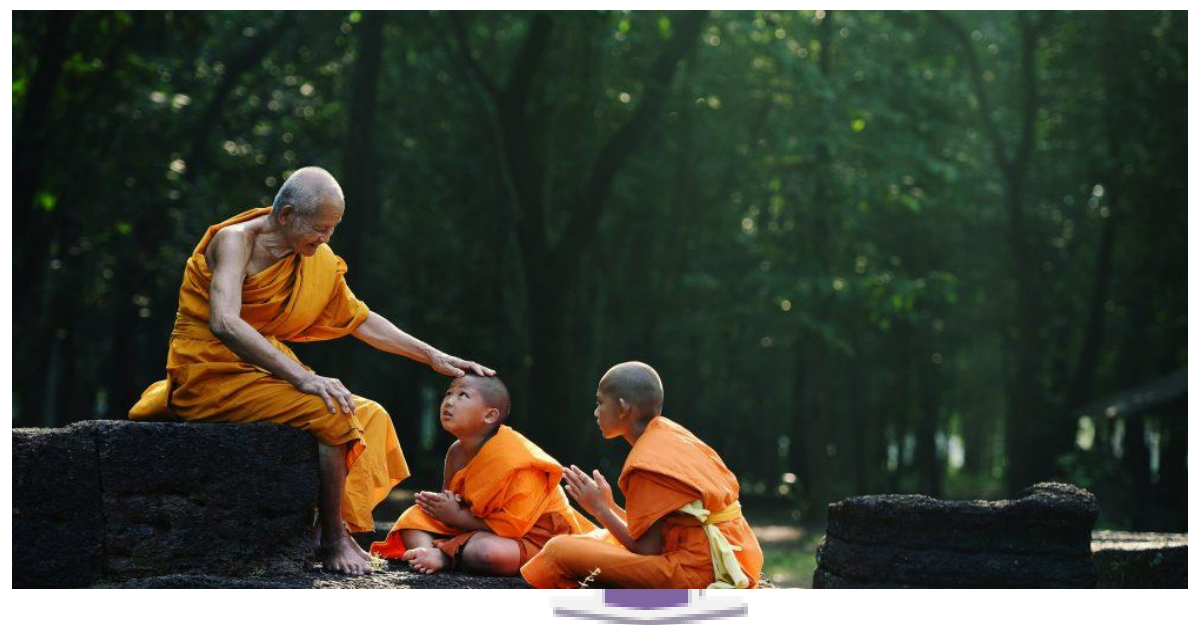

Dengan mengendapkan sifat kebencian maka Ekosistem dan siklus Kehidupan akan terjaga dengan baik, maka kebagiaan akan tercapal dan potensi bencana alam akan tertanggulangi . Sehingga setiap makluk akan terhindar dari penderitaan dan akan mencapai kebahagiaan sejati ( Nirvanal

Gambar 2. Keselarasan kehidupan dengan tidak membenci dan tidak melakukan pembunuhan

(walubi.or.id)

\section{Sutta Pitaka}

Sutta Pitaka Adalah Ajaran Sang Buddha tentang Kotbah-kotbah yang telah disampaikan selama 45 tahun, sutta Pitakan ini terbagi kedalam beberapa kitab 
seperti : Suta Pitaka menguraikan tentang semua kotbah Sang Buddha yang mencakup berbagai aspek di 31 alam kehidupan, salah satunya kehidupan manusia dengan alam, kontek kehidupan adalah segala sesuatu yang hidup, tumbuh dan berkembang adalah kehidupan termasuk tumbuh-tumbuhan, hewan, manusia dalan lainnya. Manusia bagaikan pohon dan udara, belukar, dan awan. Bila pepohonan tidak dapat hidup, manusia tidak dapat hidup pula. Manusia harus menjadi bagian dari alam semesta tersebut dan peduli terhadapnya. Memandang sehelai kertas, melihat hal-hal lain pula, awan, hutan, penebang kayu.

Dalam Agganna-sutta dijelaskan hubungan timbal-balik antara perilaku manusia dan evolusi perkembangan tumbuh-tumbuhan. Jenis padi (sali) yang pertama dikenal berupa butiran yang bersih tanpa sekam. Kemudian timbul dalam pikiran manusia, mengumpulkan padi yang cukup untuk makan siang dan makan malam sekaligus.

Pikiran berikutnya yang timbul mudah diterka lebih baik lagi kalau dikumpulkan untuk dua hari, empat hari, delapan hari, dan seterusnya. Sejak itu manusia mulai menimbun padi. Padi yang telah dituai tidak tumbuh kembali. Maka, akibat keserakahannya, manusia harus menanam dan menunggu cukup lama hingga padi yang ditanamnya berbuah. Batang-batang padi mulai tumbuh berumpun. Lalu butir-butir padi pun berkulit sekam (D. III. 88-90).

Dalam karania Sutta Sang Buddha juga menjelaskan bagaimana manusia harus hidup bersinerhi dengan alam dan lingkungan, karena lingkungn ada banyak makluk yang menghuninya baik yang kelihatan maupun yang tidak kelihatan. Bila setiap orang sudah memahami arti akan menjaga dan memanfaatkan lingkungan dengan baik tidak serakah dan tidak mementingkan diri sendiri maka lingkungan akan memberikan yang terbaik buat kehidupan manusia dan habitat lainnya. Contohnya manusia bisa menghargai hutan dan lahan dengan tidak melakukan pembakaran saat akan membuka untuk kepentingan pertanian makan alam tetap akan terjaga ekosistemnya. Namun bila seseorang sudah melakukan pembukaan lahan dan hutan dengan cara membakar maka kerusakan alam dan ekosistemnya akan terjadi dan ini akan berakibat penderitaan kepada setiap makluk.

Buddha Dharma menghubungkan lingkungan alam dan hubungan manusia yang berguna untuk menciptakan suatu atmosfir kebahagiaan dalam kehidupan di atas bumi. Buddhis menunjukkan cara pemecahan masalah krisis lingkungan. Sehubungan dengan pandangan ekologis Buddhis memperkuat sikap ramah kepada alam dan menelisik hubungan manusia, tumbuh-tumbuhan, dan binatang dari sudut keselarasan.

Tiga peristiwa utama menyangkut kehidupan Buddha, yakni kelahiran, mencapai penerangan sempurna, dan parinibbana (kematian), mengambil tempat di bawah pohon terbuka. Buddha menasihatkan kepada biarawan untuk mencari-cari tempat yang luas di tengah hutan dan kaki pohon untuk praktik meditasi. Udara 
menyegarkan, tenang, dalam suatu lingkungan alami dipertimbangkan sebagai sarana untuk pertumbuhan spiritual.

Perhatian Buddha untuk hutan dan pohon dapat dilihat dalam Vanaropa Sutta (S.I.32), yang mana konon penanaman kebun (aramaropa) dan hutan (vanaropa) adalah tindakan yang berjasa, menganugerahkan jasa siang malam sebagai penolong
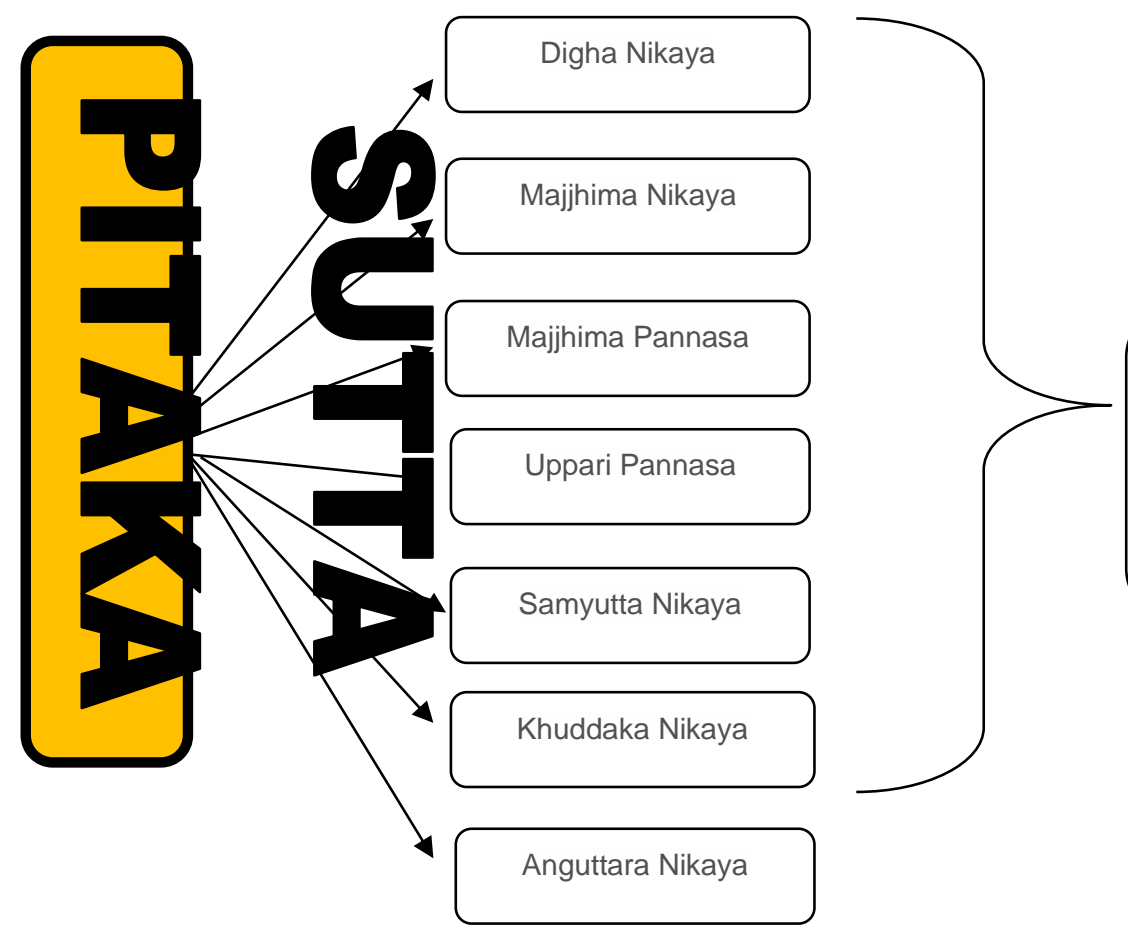

Suta Pitaka menguraikan tentang semua kotbah Sang Buddha yang mencakup berbagai aspek di 31 alam kehidupan.

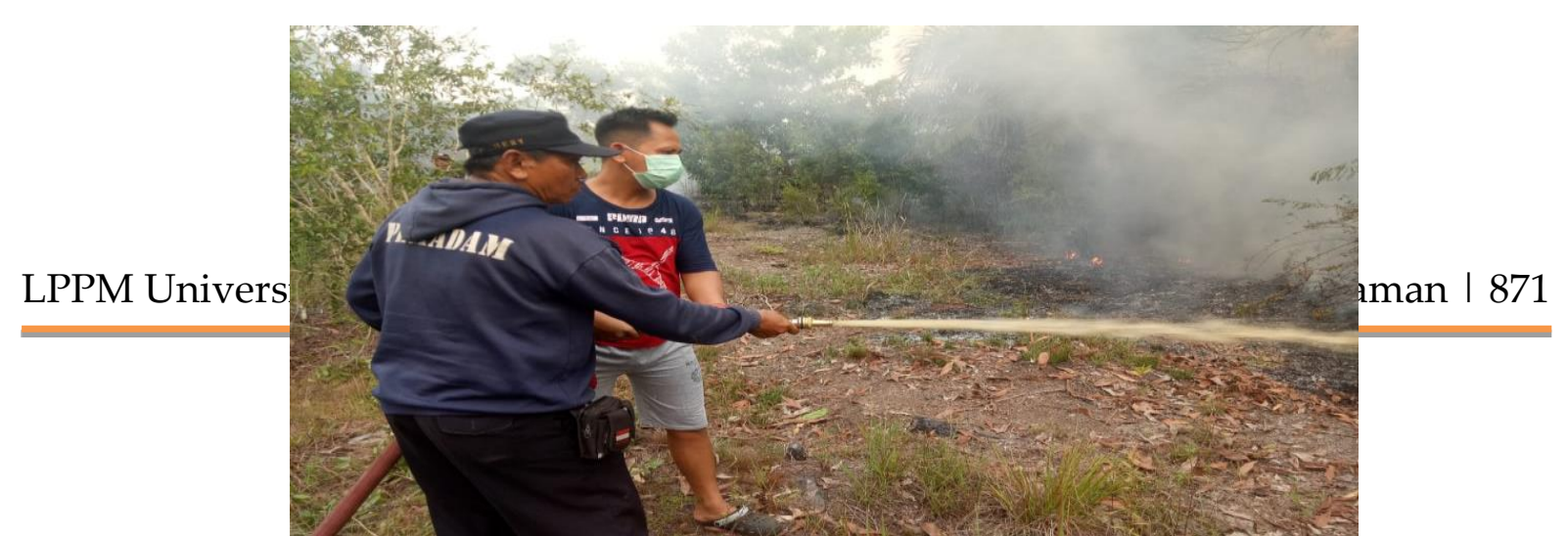


Gambar 3. Menjaga dan berperan ketika terjadi Kebakaran Lahan dan Hutan

\section{Abhidhamma Pițaka (abhidhammapițaka)}

Abhidhamma Pitaka adalah suatu kitab yang baru resmi tertuliskan pada Muktamar (sanghayana) keempat yang diselenggarakan di Aluvihara, Sri Lanka pada tahun $\underline{83}$ Sebelum Masehi. Pada mulanya, kitab ini dituliskan pada lembaran-lembaran daun lontar. Sedangkan bahasa yang digunakan adalah bahasa Pali (Magadha). Namun beberapa tahun kemudian telah terdapat pula Abhidhamma Pițaka yang ditulis dalam bahasa Sinhala, Devanagari, Myanmar, Thai, Inggris dan lain-lain. Abhidhamma Pitaka berisi tentang uraian mengenai filsafat, metafisika dan ilmu jiwa Buddha Dhamma, ini adalah ajaran Buddha pada tarap tertinggi karena Abhidhamma mengajarkan bagaimana mencapai penerangan sempurna atas dasar dari pelaksanaan Vinaya Pitaka dan Sutta Pitaka yang telah di uraikan dan dilaksanakan dengan baik.

Abhidhamma Pitaka ini adalah ajaran tertinggi yang di Sampaikan oleh Sang Buddha, karena untuk mencapai ajaran ini harus terlebih dahulu menyempurnakan Vinaya (sila), Sutta (praktek) baru masuk ke Abhidhamma. Ajaran ini merupakan ajaran untuk mencapai pandangan terang dan mempelajari semua elemen filsafat dari manusia, sehingga tingkat kebijaksanaan dalam menjalani kehidupan dan menghargai alam sudah mencapai level tertinggi. Kitab pecahan dari Abhidhamma yang terbagi menjadi tujuh kitab menerangkan berbagai hal seperti :

1) Penjelasan rinci fenomena analisa Citta dan Cetasika

2) Analisis tentang fenomena

3) Analisis tentang Unsur Khanda, Ayatana dan Dhatu

4) Tentang tipe individu menurut tingkat pencapaian

5) Pokok kontroversi tentang Buddha Dharma

6) Risalah logika terapan yang di atur berpasangan

7) Studi detail tentang sebab akibat

Perkembangan kemajuan duniawi tidak setimpal bayarannya dalam mengatasi permasalahan lingkungan. Lingkungan hidup menjadi tidak terpelihara, rusak, dan justru mengancam kehidupan manusia sendiri. Hal itu terjadi karena kehidupan nonmateri atau kemajuan rohani tidak memperoleh porsi yang semestinya. Oleh karena 
itu sangat di butuhkan tindakan nyata dalam pelaksanaan ajaran Buddha yang tertinggi, yang menjadi sumber kebahagiaan untuk manusia dan alam.
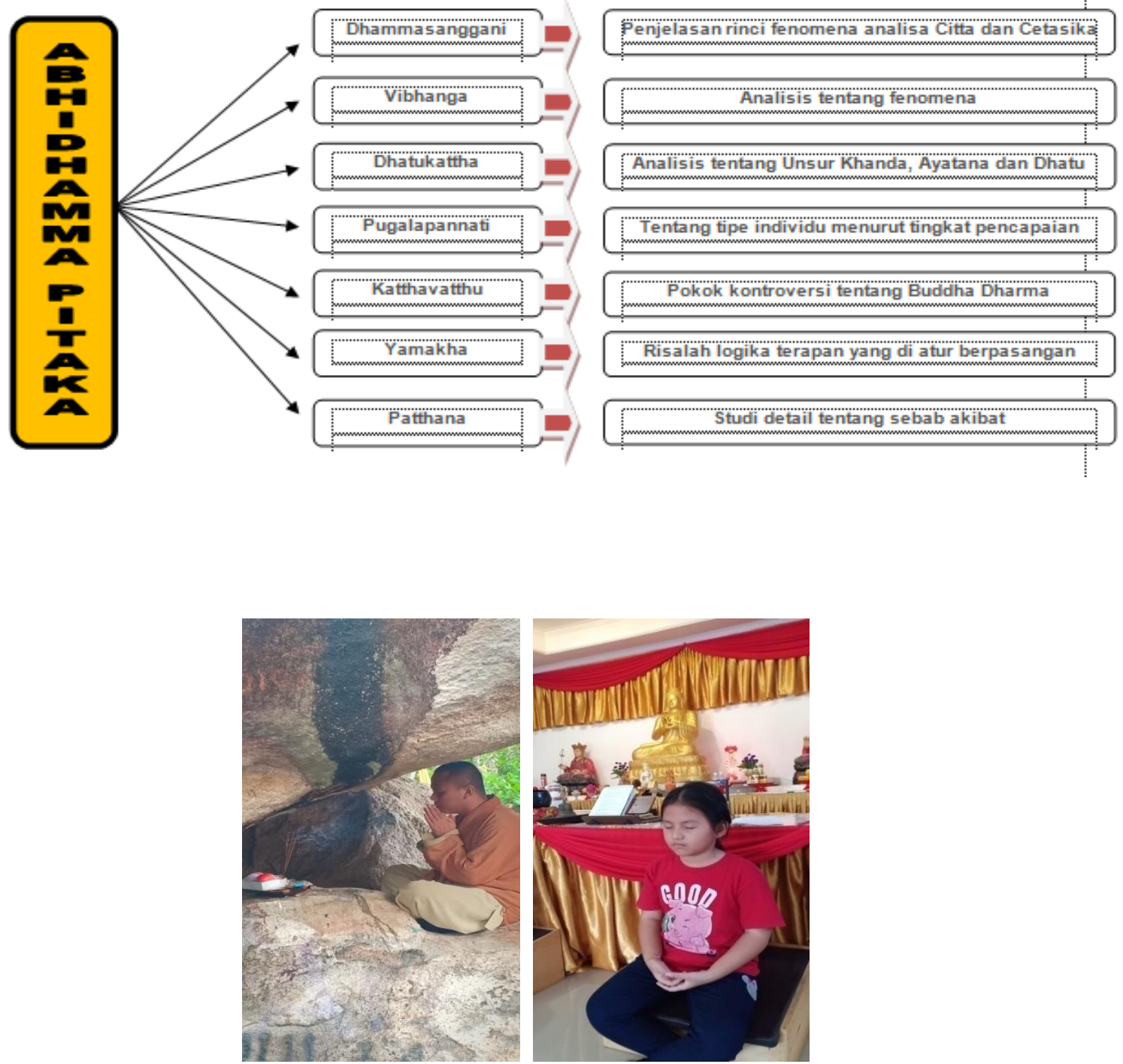

Gambar 4. Meditasi memancarkan cinta kasih yang universal kesegala penjuru alam

Implementasi ajaran Buddha terhadap lingkungan sudah dilakukan oleh umat Buddha dari berbagai belahan dunia, karena lingkungan fisik dari suatu daerah mengkondisikan pertumbuhan dan perkembangan komponen biologisnya, yaitu flora dan fauna. Ini pada gilirannya mempengaruhi pola pikir orang-orang yang berinteraksi dengannya. Cara berpikir menentukan standar moral. Proses interaksi yang berlawanan juga dimungkinkan. Moral manusia tidak hanya mempengaruhi susunan psikologis masyarakat tetapi juga lingkungan biologis dan fisik daerah tersebut. Dengan demikian, lima hukum menunjukkan bahwa manusia dan alam terikat bersama dalam hubungan sebab akibat timbal balik dengan perubahan dalam satu yang tentu saja membawa perubahan dalam yang lain. Dalam TRI PITAKA ada 
5 hukum alam yang mempengaruhin siklus kehidupan, hukum alam ini disebut Dhamma Niyama atau Lima Hukum Alam atau Lima Hukum Tertib Kosmis (pañcaniyāmadhamma) adalah salah satu konsep dalam ajaran agama Buddha mengenai hukum-hukum yang bekerja di seluruh alam semesta. Pañcaniyāmadhamma terdiri atas kata pañca yang artinya lima, niyāma yang artinya ketentuan atau hukum, dan dhamma yang artinya segala sesuatu, hukum tersebut di urakan sebagai berikut:

\section{UTU NIYAMA ( Hukum Musim )}

Adalah hukum tertib "Physical inorganik" misalnya : gejala timbulnya angin dan hujan yang mencakup pula tertib silih bergantinya musim-musim dan perubahan iklim yang disebabkan oleh angin, hujan, sifat-sifat panas, sifat benda seperti gas, cair dan padat, kecepatan cahaya, terbentuk dan hancurnya tata surya dan sebagainya. Semua aspek fisika dari alam diatur oleh hukum ini.

\section{BIJA NIYAMA( Hukum Biologis )}

Adalah hukum tertib yang mengatur tumbuh-tumbuhan dari benih/biji-bijian dan pertumbuhan tanam-tanaman, misalnya padi berasal dari tumbuhnya benih padi, manisnya gula berasal dari batang tebu atau madu, adanya keistimewaan daripada berbagai jenis buah-buahan, hukum genetika /penurunan sifat dan sebagainya . Semua aspek Biologis makhluk hidup diatur oleh hukum ini. Bija berarti "benih" di mana tumbuhan tumbuh dan berkembang darinya dalam berbagai bentuk. Dari pandangan filosofi, hukum pembenihan hanyalah bentuk lain dari hukum energi. Dengan demikian pengatur perkembangan dan pertumbuhan dunia tumbuhan merupakan hukum energi yang cenderung mewujudkan kehidupan tumbuhan dan disebut Bija-niyama. Hukum pembenihan menentukan kecambah, tunas, batang, cabang, ranting, daun, bunga, dan buah di mana dapat tumbuh. Dengan demikian, biji jambu tidak akan berhenti menghasilkan keturunan spesies jambu yang sama. Hal ini juga berlaku untuk semua jenis tumbuhan lainnya dan tidak ada sosok pencipta yang mengaturnya.

\section{KAMMA NIYAMA ( Hukum Perbuatan )}

Adalah hukum tertib yang mengatur sebab akibat dari perbuatan, misalnya : perbuatan baik / membahagiakan dan perbuatan buruk terhadap pihak lain, menghasilkan pula akibat baik dan buruk yang sesuai. Perbuatan (kamma) merupakan perbuatan baik maupun buruk yang dilakukan seseorang yang disertai kehendak (cetana). Seperti yang disebutkan dalam kitab Pali: 
"Aku katakan, Kehendak adalah Kamma, karena didahului oleh kehendak, seseorang lalu bertindak dengan jasmani, ucapan dan pikiran ".

(Anguttara Nikaya III : 415)

Disini, kehendak merupakan kemauan (tindakan mental). Dalam melakukan sesuatu, baik maupun buruk, kehendak mempertimbangkan dan memutuskan langkahlangkah yang diambil, menjadi pemimpin semua fungsi mental yang terlibat dalam perbuatan tersebut. Ia menyediakan tekanan mental pada fungsi-fungsi ini terhadap objek yang diinginkan. Dalam melaksanakan tugasnya, termasuk juga tugas-tugas semua proses mental lainnya yang terlibat, kehendak menjadi pemimpin tertinggi dalam pengertian ia memberitahukan semua sisanya. Kehendak menyebabkan semua aktivitas mental cenderung bergerak dalam satu arah.

\section{CITTA NIYAMA ( Hukum Psikologis )}

Adalah hukum tertib mengenai proses jalannya alam pikiran atau hukum alam batiniah, misalnya : proses kesadaran, timbul dan lenyapnya kesadaran, sifat-sifat kesadaran, kekuatan pikiran / batin (Abhinna), serta fenomena ekstrasensorik seperti Telepati, kewaskitaan (Clairvoyance), kemampuan untuk mengingat hal-hal yang telah lampau, kemampuan untuk mengetahui hal-hal yang akan terjadi dalam jangka pendek atau jauh, kemampuan membaca pikiran orang lain, dan semua gejala batiniah yang kini masih belum terpecahkan oleh ilmu pengetahuan modern termasuk dalam hukum terakhir ini. Citta berarti "yang berpikir" (perbuatan berpikir), yang mengandung pengertian: yang menyadari suatu objek. Juga berarti: menyelidiki atau memeriksa suatu objek. Lebih jauh lagi, citta dikatakan berbedabeda bergantung pada berbagai bentuk pikiran atas objek.

\section{DHAMMA NIYAMA ( Fenomena Alam)}

Adalah hukum tertib yang mengatur sebab-sebab terjadinya keselarasan /persamaan dari satu gejala yang khas, misalnya : terjadinya keajaiban alam seperti bumi bergetar pada waktu seseorang Bodhisattva hendak mengakhiri hidupnya sebagai seorang calon Buddha, atau pada saat Ia akan terlahir untuk menjadi Buddha. Hukum gaya berat (gravitasi), daya listrik, gerakan gelombang dan sebagainya, termasuk dalam hukum ini. Dhamma adalah sesuatu yang menghasilkan sifat dasarnya sendiri (dhareti), yaitu kekerasannya sendiri ketika disentuh, sifat khusus sekaligus sifat universalnya adalah berkembang, melapuk, hancur, dan seterusnya. Dhamma yang dikategorikan dalam hubungan sebab "menghasilkan" fungsi hubungan sebab tersebut, dan yang dikategorikan dalam hubungan akibat "menghasilkan" fungsi akibat atau hasil. Pengertian ini meliputi semua Dhamma yang dibahas dalam Suttanta dan Abhidhamma Pitaka. Ini juga 
meliputi hal-hal yang disebutkan dalam Vinaya Pitaka dengan nama "tubuh aturan" (silakkhandha).

\section{Interpretasi Tokoh Agama Buddha Terhadap Lingkungan Hidup dan Karhutla}

Tabel 1 menunjukkan pendapat dan peran tokoh agama Buddha dalam perlindungan terhadap lingkungan hidup dan dikaitkan dengan karhutla. Pada tahap ini para tokoh akan diarahkan untuk melakukan reka ulang tentang apa yang sudah dilakukan. Berbagai kegiatan nyata yang sudah dilakukan oleh umat Buddha seperti menyiarkan melalui dahwah tentang bahaya kebakaran hutan dan lahan, melakukan kegiatan sosial seperti pengobatan gratis di tempat-tempat yang berdampak kabut asap, membagikan masker dan vitamin, serta kegiatan bersifat terjun langsung seperti Fangshen (pelepasan makluk hidup kehabitatnya aslinya) dan menanam pohon.

\section{Aktivitas Pelestarian Lingkungan dalam Komunitas Umat Buddha}

Praktek nyata yang harus dilakukan oleh umat Buddha untuk menjaga ekosistem dalam keseimbangan lingkungan dan menjaga lingkungan dengan cara melakukan berbagai upaya seperti:

\section{Fangshen (pelepasan makluk hidup)}

Melakukan fangshen (pelepasan makluk hidup) kehabitat aslinya, hal ini merupaka penerapan sila pertama dalam pancasila Buddhis yaitu : Pānāatipātā veramaṇī sikkhāpadam samādiyāmi yang artinya Aku bertekad melatih diri untuk menghindari pembunuhan makhluk hidup. Hal ini yang banyak di lakukan oleh umat Buddha di seluruh dunia bahkan perkembangan kegiatan ini berkembang pesat di Indonesia, bahkan di provisi Kalimantan Tengah pun juga melakukan kegiatan Fangshe di berbagai vihara yang ada di wilayah kalimantan Tengah.

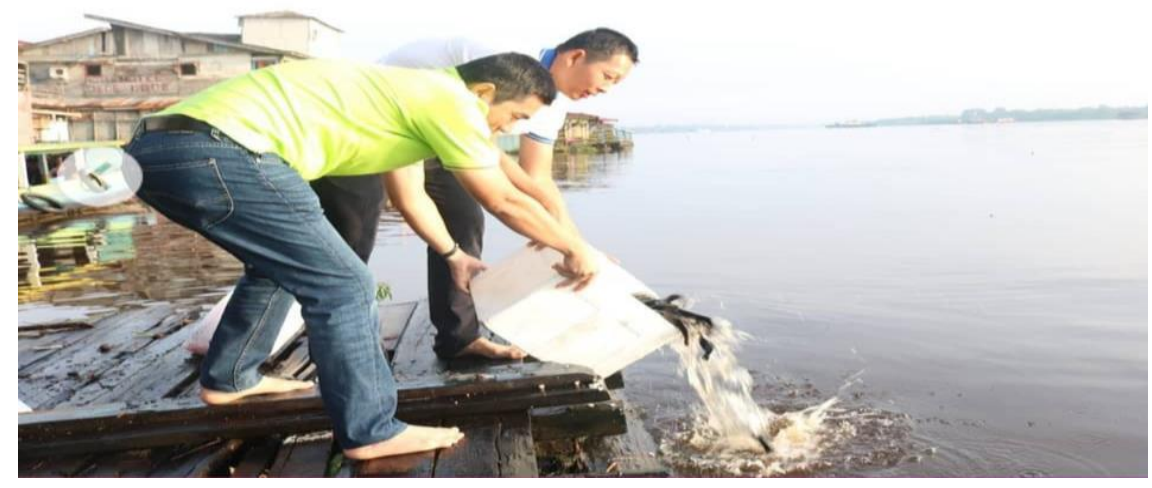


Gambar 5. Tokoh Umat Buddha Kab. Kotawaringin Timur sedang melakukan

Fangshen Ikan di Sungai mentaya bersama beberapa umat Buddha dalam rangka menjaga ekosistem

\section{Pembersihan Lingkungan}

Kegiatan yang terus dilakukan umat Buddha bersama dengan masyarakat umum adalah menjaga kondisi lingangn agar tetap bersih dari kotoran sampah terutama di pesisir pantai, sesuai dengan ajaran Buddha pengembangan cinta kasih dan keperdulian terhadap lingkungan harus tetap ditumbuhkan dalam diri umat Buddha. sifat kepedulian ini akan menjadikan suri tauladan kepada umat lain dan membantu terhindar dari bencana alam yang sehingga mengurangin penderitaan semua makluk hidup.

Poko kesadaran umat Buddhha menjadi kunci dalam mempraktekan ajaran Buddha yang tetap memegangtenguh ajaranBuddha tetang cinta kasih yang universal, kegiatan nyata ini dilakukan oleh umat Buddha di Vihara Karuna maitreya yang tergabung dalam Majelis Mapambumi Prov. Kalteng. Peran serta umat Buddha dalam memberikan kontribusi dalam menjaga ekosistem terutama di Kalimantan Tengah menjadi tugas semua elemen umat Budha.

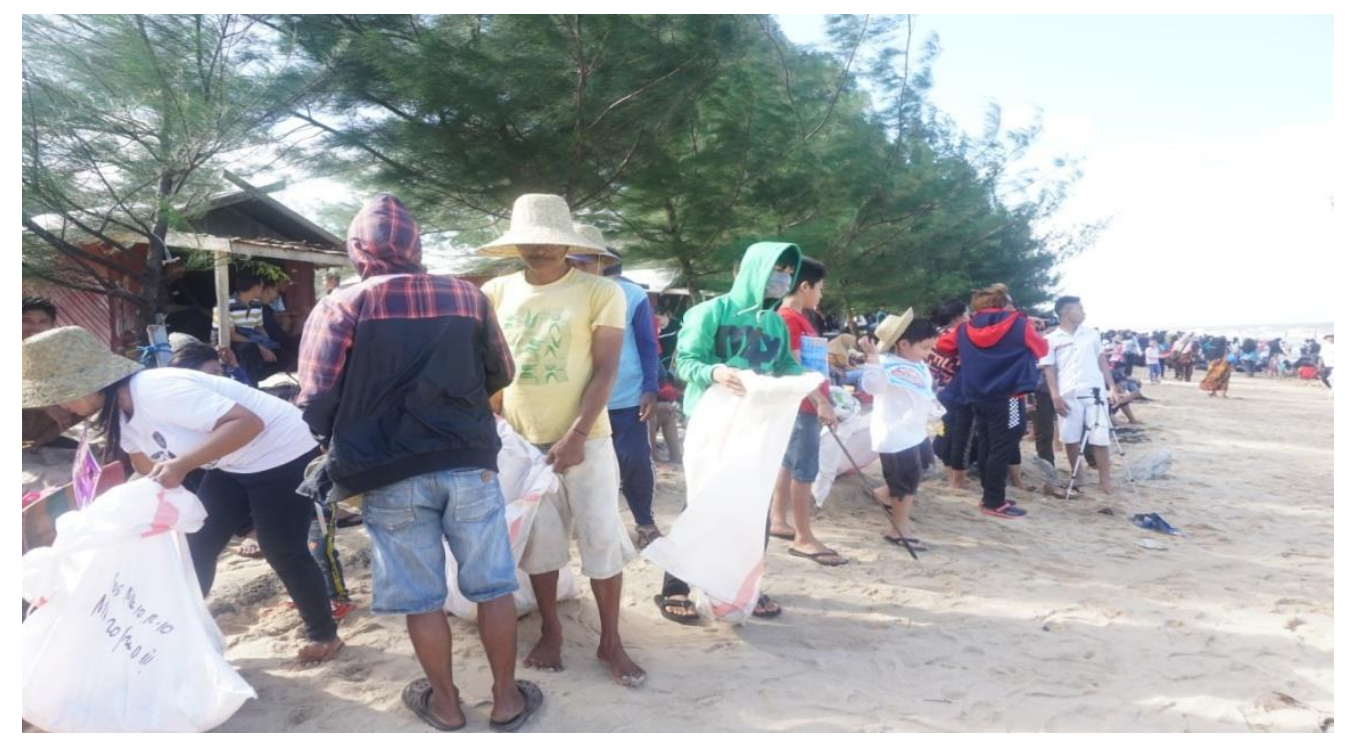

Gambar 6. Kegiatan Umat Buddha Vihara Karuna Maitreya Sampit bersama para Masyarakat sekitar membersihkan sampah di pesisir pantai di Kabupaten Kotawaringin Timur

Pembagian Masker 
Kebkaran hutan dan lahan di Kalimantan Tengah setiap tahun selalu terjadi baik sekala kecil maupun besar, hal ini akan menjadi kendala dalam perkembangan dari segala sisi. Kebakaran hutan dan lahan di Kalimantan Tengah umumnya (99,9\%) disebabkan oleh manusia, baik disengaja maupunakibat kelalaiannya. Sisanya $(0,1 \%)$ disebabkan faktor alam, seperti petir dan lava gunung berapi. Penyebab kebakaran oleh manusia dapat diperinci sebagaiberikut:

1. Konversi lahan untuk pertanian, industri, pembuatanjalan, jembatan, bangunan, dan lain-lain;

2. Pembakaranvegetasi yang disengaja tetapi tidak terkendali, sepertipembukaan areal HTI, perkebunan, dan penyiapan lahan olehmasyarakat;

3. Aktivitas dalam pemanfaatan sumber dayaalam, seperti pembakaran semak belukar untuk akses masukhutan dan pembuatan api untuk memasak oleh para penebangliar dan pencari ikan di dalam hutan;

4. Aktivitas pembakaransekitar kanal didukung oleh keringnya gambut di sekitar kanal;

5. Pembakaran untuk menunjukkan penguasaan lahan olehmasyarakat setelah terambil perusahaan dan bahkan, pembakaranuntuk merambah areal hutan.

Kebakaran hutan dan lahan menjadi Trending topi setiap tahun dan selalu memberika PR buat pemerintah dalam upaya menanganinya. Akibat kebakaran hutan dan lahan ini menyebakan beberapa faktor besara seperti :

1. Dampak Kesehatan

2. Pencemaran Lingkungan

3. Terganggunya Stabilitas Ekonomi, Sosial dan Budaya, serta Ekosistem

4. Tersedotnya Anggaran Negara

5. Menurunnya Devisa Negara

6. Tuntutan dari Negara lain

Toko agama juga merupkan sentral dalam penanganan kebakaran hutan dan lahan, melalui gerakan tokoh agama yang menjadi panutan umat bisa lebih efektif karena melalui penyiaraan dahwah agama kepada umatnya setiap saat. Adanya kerjasama pemerintah dengan para tokoh agama untuk menyampaikan tentang bahayanya kejadian kebkaran hutan dan lahan yang mengakibatkan banyaknya gangguan.

Para tokoh dan umat Buddha juga beperan dalam penanganan akibat kebkaran hutan dan lahan seperti pembagian masker kepada banyak masyarakat dan siswa, pembagian sembako kepada masyarakat yang terdampak, karena ini merupaka prakteknyata yang harus dilakukan oleh umat Buddha.

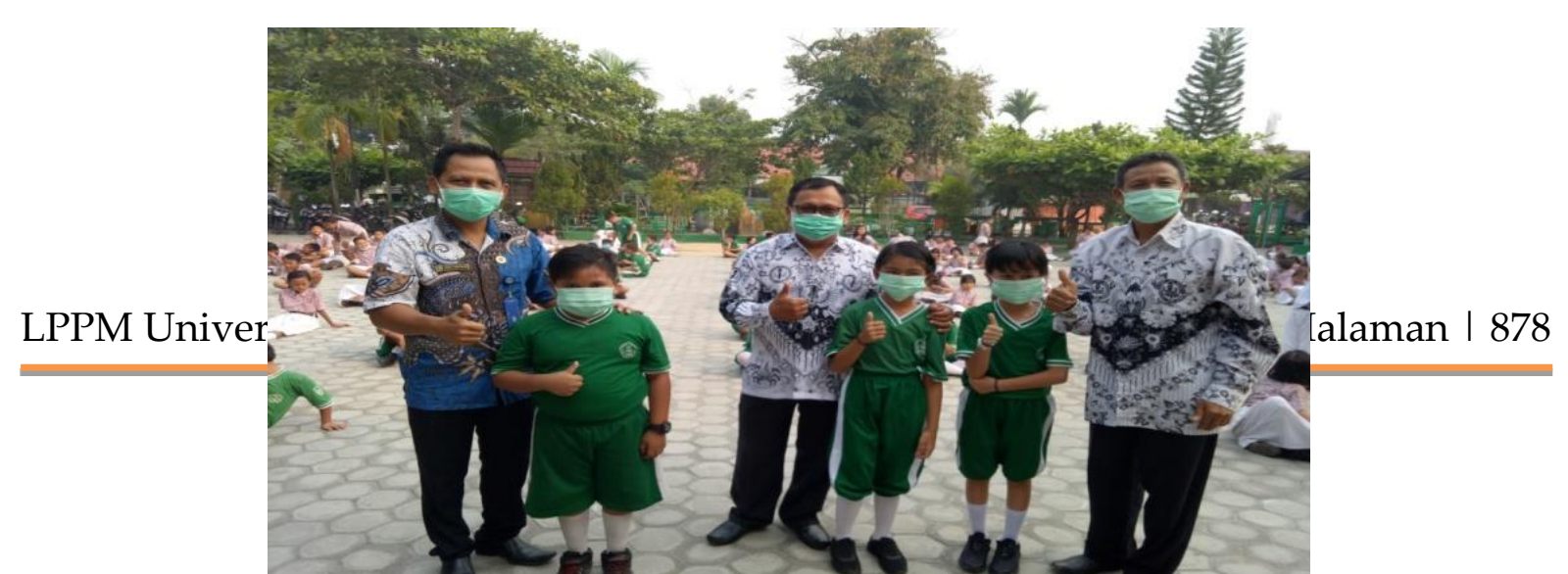


Gambar 7. Pembagian Masker kepada Siwa siswi bersama Guru Agama Buddha

\section{KESIMPULAN DAN SARAN}

Kebakaran hutan dan lahan menjadi pokok permasalahan yang harus diselesaikan dengan berbagai cara salah satunya dengan pendekatan secara agama, ajaran Buddha menjadi memiliki ajaran yang dapat membantu dalam memberikan pemahaman dan prakteknya dalam menangani kebakaran hutan dan lahan dan dampaknya. Pokok ajaran Buddha dalam menanggulangi kebakaran hutan dan lahan adalah pengendalian diri, kendalikan ego, mengikikis 3 (tiga) akar kejahatan yaitu LOBHA (Keserakahan), DOSA (Kebencian) dan MOHA (Ketidak tahuan) serta mengembangkan cinta kasih yang universal kepada semua makluk. Praktek nyata yang telah dilakukan oleh umat Buddha untuk menjaga dan melestarikan lingkungan adalan dengan beberapa kegiatan seperti FNGSHEN (Pelepasan makluk hidup) kehabitat aslinya, melakukan penanaman pohon, membersikan sampah yang menumpuk di lingkungan dan melakukan pembagian masker kepada para siswa sekolah dan masyarakat serta ikut aksi pemadaman. Penelitian ini menyarakan kepada semua pihak baik pemerintah, aparat hukum dan para tokoh lintas agama dan masyarakat untuk bersama-sama memberikan pemahaman kepada masyarakat agar kebakaran hutan dan lahan di Kalimantan Tengah dapat ditanggulanggi dan di cegah.

\section{DAFTAR PUSTAKA}

Chen, S., Chen, L., Liu, Q., Li, X., Tan, Q. 2005. Remote sensing and GIS based integrated analysis of coastal changes and their environmental impacts in Lingding Bay, Pearl River Estuary, South China. Ocean and Coastal Management, 6 (48): 65-83.

Eryani, I.G.A.P., Ardantha, I.M., Sinartha, I.N. 2009. Pengaruh Perubahan Iklim Global terhadap Karakteristik Kerusakan Pantai di Kabupaten Badung, Provinsi Bali. Bali, Indonesia: Pusat Penelitian Lingkungan Hidup, Warmadewa University. 
Handoko, P. 2007. “Mediasi Konflik Penanganan Kerusakan Pantai: Studi kasus Penanganan Abrasi Pantai Kuta Bali" (thesis). Semarang: Diponegoro University.

Komar, P. D. 1983. Beach Processes and Erosion. In: Komar, P.D., Moore, J.R., editors. CRC Handbook of Coastal Processes and Erosion. $3^{\text {rd }}$ Ed. Boca Raton, Florida: CRC Press Inc. p.1-20.

Philander, S.G. 1990. El Niño, La Niña, and the Southern Oscillation. San Diego, CA: Academic Press. 289 pp.

Bhikkhu Buddhadasa. (2006). The Truth of Nature Tanya Jawab dengan Bhikkhu

Buddhadasa tentang Ajaran Budha. Yayasan Penerbit Karaniya: Unesco gret international personality.

Cornelis Wowor. (2005). Pandangan Sosial Agama Buddha. Vihara Tanah Putih, Semarang.

Daradjat Zakiyah. (1996). Perbandingan Agama. Bumi Aksara: Jakarta. Eng Soon Teoh. (2006). Guanyin Seratus Satu Pertanyaan. Karaniya: t.tp.

Hayes, Richard. (1988). Principled Atheism in the Buddhist Scholastic Tradition. Journal of Indian Philosophy.

Jirhanuddin (2010) Perbandingan Agama Pengantar Studi Memahami Agama-Agama. Pustaka Pelajar: Yokyakarta.

Kitab Suci Sutta Pitaka. (1988). Sutta Pitaka Digha nikaya. C.V Lovina Indah: Jakarta. Kitab Suci Udana. (1988). Sutta Pitaka Digha nikaya. C.V Lovina Indah: Jakarta.

Kitab suci Dhammapada. (2002). Sabda-Sabda Buddha Gotama. Dewi Kayana Abadi Jakarta.

Muhamadin (2009), Agama-Agama di Dunia, Awfamedia: Palembang.

Nawawi Imam. (2011) Riyadhus Shalihin Perjalanan Menuju Taman Surga. Jabal: Bandung

Sayadawu Silanda. (2003) Kamma (Hukum Sebab Akibat), Anatta (Doktrin Tiada Inti Diri). Karaniya.

Willy Yandi Wijaya, Ekologis Buddhis.Jakarta 2002.

Willy Yandi Wijaya ; Evolusi Kesadaran Menuju Pencerahan, Jakarta 2004.

Itivuttaka 3.1; Khunddaka Nikaya, Tripitaka cetakan pertama 2001. 